Yusli Mariadi., Isnawati, \& Zuhrotul Isnaini : Dampak Nilai Final Terhadap Kinerja .....

\title{
DAMPAK NILAI FINAL TERHADAP KINERJA DOSEN DALAM PERSPEKTIF MAHASISWA AKUNTANSI
}

\author{
Yusli Mariadi \\ Fakultas Ekonomi Dan Bisnis Universitas Mataram \\ yusli.mariadi@gmail.com \\ Isnawati \\ Fakultas Ekonomi Dan Bisnis Universitas Mataram \\ Isnawati.isna@unram.ac.id \\ Zuhrotul Isnaini \\ Fakultas Ekonomi Dan Bisnis Universitas Mataram \\ zuhrotul.isnaini@unram.ac.id
}

\begin{abstract}
The lecturer performance appraisal in lectures was conducted by distributing questionnaires to find out the opinions of students during the lectures conducted. Assessment is carried out on 10 (ten) elements with the rating scale used $1-5$. The assessment of students on lecturer performance show different results for the same lecturer in each semester. This fact raises questions in the mind of the author with the differences in the results of this assessment. Is there anything (factor) that affects the difference in the results of this assessment, such as giving Final Values by lecturers to students. So that students who judge lecturers who give them good grades will give a good assessment to the lecturers in question, and vice versa will give a bad value for lecturers who describe the final value that is less satisfying for the students concerned. But the results of the study show that the final score did not have a significant impact on the assessment of student performance towards the lecturer. This is possible because the assessment data provided by students does not show the actual assessment, both the data before and after the final score.
\end{abstract}

Keywords: Performance; Final Values; Lectuter.

\begin{abstract}
Abstrak
Penilaian kinerja dosen dalam perkuliahan dilakukan dengan penyebaran kuesioner untuk mengetahui pendapat mahasiswa selama perkuliahan yang dilakukan. Penilaian dilakukan terhadap 10 (sepuluh) unsure dengan Skala penilaian yang digunakan 1 - 5 dimana nilai 5 = sangat baik; nilai 4 =baik, nilai 3 = cukup,
\end{abstract}


nilai 2 = kurang, nilai 1 = sangat kurang. Dan sejauH ini penilain mahasiswa terhadap kinerja dosen berbeda-beda untuk setiap semesternya. Jika melihat hasil penilaian yang diberikan mahasiswa tersebut terhadap dosennya menunjukkan hasil yang berbeda untuk dosen yang sama di setiap semesternya. Kenyataan ini memunculkan pertanyaan dibenak penulis dengan adanya perbedaan hasil penilaian ini. Adakah hal (factor) yang mempengaruhi perbedaan hasil penilaian ini, seperti pemberian Nilai Final oleh dosen kepada mahasiswa. Sehingga untuk mahasiswa yang menilai dosen yang memberikannya nilai bagus, akan memberikan penilaian yang baik kepada dosen yang bersangkutan, begitu juga sebaliknya akan memberikan nilai yang kurang baik untuk dosen yang memerikan nilai final yang kurang memuaskan bagi mahasiswa yang bersangkutan. Jenis penelitian ini adalah penelitian deskriptif. Dan setelah dilakukan uji beda untuk penilaian mahasiswa untuk kinerja dosennya dengan data sebelum dan setelah pemberian nilai final oleh dosen yang bersangkutan, maka hasil penelitian menunjukkan bahwa pemberian nilai final ternyata tidak memberikan dampak yang signifikan terhadap penilain kinerja mahasiswa terhadap dosennya. Hal ini kemungkinan karena data penilaian yang diberikan oleh mahasiswa tidak menunjukkan penilaian yang sebenarnya, baik data sebelum maupun sesudah pemberian nilai final. Dimungkinkan mahasiswa hanya sekedar mengisi dan melingkari angka penilaian, karena antara nilai yang diberikan tidak cocok dengan saran yang diberikan oleh mahasiswa kepada dosennya.

\section{Kata kunci : Kinerja ; Perspektif; AKuntansi; Nilai Final}

\section{PENDAHULUAN}

Penerbitan Undang-Undang Nomor 12 Tahun 2012 tentang Pendidikan

Tinggi (UU Dikti) mengokohkan Sistem Penjaminan Mutu Perguruan Tinggi

yang telah dilaksanakan sejak tahun 2008. Walaupun dengan nama baru yaitu Sistem Penjaminan Mutu Pendidikan Tinggi, sebagai sebuah system tetap mengintegrasikan tiga pilar yaitu; a) Sistem Penjaminan Mutu Internal yang dilaksanakan oleh setiap perguruan tinggi; b) Sistem Penjaminan Mutu 
Yusli Mariadi., Isnawati, \& Zuhrotul Isnaini : Dampak Nilai Final Terhadap Kinerja .....

Eksternal atau Akreditasi yang dilaksanakan oleh Badan Akreditasi Perguruan Tinggi atau Lembaga Akreditasi Mandiri; dan c) Pangkalan Data Pendidikan Tinggi baik pada aras perguruan tinggi maupun aras Kementrian Riset, Teknologi, dan Pendidikan Tinggi.

Pengaturan Sistem Penjaminan Mutu Pendidikan Tinggi (SPM Dikti) di dalam UU Dikti, semua perguruan tinggi di Indonesia berkewajiban menjalankan SPM Dikti tersebut dengan modus yang paling sesuai sejarah, visi, misi, mandate, ukuran, budaya organisasi perguruan tinggi yang bersangkutan. System Penjaminan Mutu Perguruan Tinggi tersebut telah dituangkan dalam sebuah buku berjudul Sistem Penjaminan Mutu Perguruan Tinggi pada Tahun 2008 yang dibuat dalam dua bahasa, yaitu bahasa Indonesia dan bahasa Inggris.

Menurut Pasal 51 UU Dikti, Pendidikan Tinggi yang bermutu merupakan pendidikan tinggi yang menghasilkan lulusan yang mampu secara aktif mengembangkan potensinya dan menghasilkan ilmu pengetahuan dan /atau teknologi yang berguna bagi masyarakat, bangsa dan negara. Untuk mendapatkan pendidikan tinggi yang bermutu tersebut, Pemerintah menyelenggarakan Sistem Penjaminan Mutu Pendidikan Tinggi (SPM DIkti). Setiap perguruan tinggi dapat mengembangkan sendiri SPMI antara lain sesuai dengan latar belakang sejarah, nilai dasar yang menjiwai pendirian 
perguruan tinggi itu, jumlah program studi dan sumber daya manusia, sarana dan prasarana perguruan tinggi tersebut tanpa campur tangan pihak lain.

Universitas Mataram (Unram) yang merupakan salah satu Perguruan Tinggi Negeri di Nusa Tenggara Barat tentunya juga tunduk pada berabagai aturan yang dikeluarkan oleh Pemerintah tentang Pendidikan, tidak terkecuali UU Dikti yang memuat tentang penjaminan mutu pelaksanaan pendidikan di lingkungan perguruan tinggi. Dalam Peraturan Meneteri Pendidikan dan Kebudayaan RI Nomor 116 Tahun 2014 tentang Organisasi dan Tata Kerja Uniersitas Mataram membentuk lembaga yang merupakan unsure pelaksana akademik di bawah Rektor yang melaksanakan sebagian tugas dan fungsi di bidang penelitian, pengabdian kepada Masyarakat, penjaminan mutu dan pengembangan pendidikan.

Fakultas Ekonomi dan Bisnis Unram (FEB Unram) merupakan salah satu unit pendidikan yang secara rutin menjalankan UU Dikti terkait dengan penjaminan mutu. Untuk mendukung UU tersebut, FEB Unram membentuk gugus dan unit penjaminan mutu untuk melakuukan evaluasi terhadap penyelenggaraan berbagai program dan kegiatan pembelajaran di Lingkungan Fakultas Ekonomi dan Bisnis Universitas Mataram. Evaluasi dilaksanakan oleh Gugus Penjaminan Mutu fakultas dibantu oleh unit penjaminan masing-masing jurusan dan program studi yang ada di 
Yusli Mariadi., Isnawati, \& Zuhrotul Isnaini : Dampak Nilai Final Terhadap Kinerja .....

lingkungan FEB Unram, salah satunya adalah unit penjaminan mutu Jurusan/Program Studi Akuntansi.

Unit Penjaminan mutu Program Studi Akuntansi berada di bawah Gugus Penjaminan Mutu FEB Unram. Dalam melakukan penjaminan mutu, unit penjaminan mutu membuat berbagai standar yang akan diacu dalam pelaksanaan kegiatan. Standar-standar tersebut dibuat dan dikoordinasikan dengan pengelolan Program Studi. Gugus dan Penjaminan Mutu FEB Mataram melaksanakan beberapa kegiatan antara lain: a) Penyusunan Instrumen evaluasi; b) penyusunan POB; c) Evaluasi penelitian; d) Evaluasi pengabdian pada Masyarakat; e) Evaluasi pembimbingan tugas akhir.

Selama ini Penilaian kinerja dosen dalam perkuliahan dilakukan dengan penyebaran kuesioner untuk mengetahui respon/pendapat mahasiswa selama perkuliahan yang dilakukan. Penilaian dilakukan terhadap 10 (sepuluh) unsure dengan Skala penilaian yang digunakan $1-5$ dimana nilai $5=$ sangat baik; nilai $4=$ baik, nilai $3=$ cukup, nilai $2=$ kurang, nilai $1=$ sangat kurang. Dan sejau ini penilain mahasiswa terhadap kinerja dosen berbeda-beda untuk setiap semesternya. seperti halnya yang tertuang pada Laporan penjaminan Mutu Program Studi D3 Akuntansi untuk semester Gasal dan Genap pada Tahun ajaran 2016/2017. Hasil evaluasi kinerja dosen menurut mahasiswa pada semester Gasal 2016/2017 memperlihatkan hasil rata-rata sebesar 4,14. 
Hal ini menunjukkan mahasiswa menganggap bahwa dalam pemberian perkuliahan dosen telah melakukan tugasnya dengan baik. Sedangkan pada semester Genap 2016/2017 menunjukkan hasil yang berbeda dengan semester sebelumnya. Rata-rata nilai kinerja dosen dalam perspektif mahasiswa sebesar 3,89. Hal ini memberikan arti bahwa mahasiswa menganggap bahwa dalam memberikan perkuliahan dosen telah melakukan tugasnya dengan cukup baik.

Jika melihat hasil penilaian yang diberikan mahasiswa tersebut terhadap dosennya menunjukkan hasil yang berbeda untuk dosen yang sama di setiap semesternya. Kenyataan ini memunculkan pertanyaan dibenak penulis dengan adanya perbedaan hasil penilaian ini. Adakah hal (factor) yang mempengaruhi perbedaan hasil penilaian ini, seperti pemberian Nilai Final oleh dosen kepada mahasiswa. Sehingga untuk mahasiswa yang menilai dosen yang memberikannya nilai bagus, akan memberikan penilaian yang baik kepada dosen yang bersangkutan, begitu juga sebaliknya akan memberikan nilai yang kurang baik untuk dosen yang memerikan nilai final yang kurang memuaskan bagi mahasiswa yang bersangkutan. Mengingat selama ini pemberian kuesioner kepada mahasiswa dilakukan setelah nilai akhir ujian sudah diumumkan. Selain itu juga pembagian kuesioner dilakukan 
dengan menggunakan sample sebanyak 10 mahasiswa untuk menilai setiap dosen yang pernah mengajar pada semester sebelumnya.

Berdasarkan penjelasan latar belakang tersebut, maka penelitian ini tertarik untuk menilai kembali kinerja dosen dari perspektif mahasiswa akuntansi sebelum dan setelah ujian akhir, lebih tepatya sebelum dan sesudah pemberian nilai final oleh setiap dosen. Hal ini dilakukan untuk mengetahui adakah dampak dari nilai final terhadap kinerja dosen dari perspektif mahasiswa akuntansi?.diharapkan nantinya hasil penelitian ini dapat menjadi bahan masukan untuk tim penjaminan mutu yang ada di Lingkungan Unram pada umumnya dan lingkungan Fakultas Ekonomi dan Bisnis pada khususnya untuk bisa mempertimbangkan waktu yang tepat dalam pemberian kuesioner kepada mahasiswa dalam kaitannya mendapatkan input penilaian kinerja dalam perspektif mereka. Sehingga hasil penilaian yang dilaporkan oleh tim penjaminan mutu bisa seobjektif mungkin. 


\section{TELAAH LITERATUR DAN PENGEMBANGAN HIPOTESIS}

\section{Dasar Hukum Sistem Penjaminan Mutu Pendidikan Tinggi (SPM Dikti)}

Sebagaimana dikemukakan di atas bahwa dasar hokum implementasi SPM Dikti ini adalah Undang-Undang Dikti. Di dalam UU Dikti terdapat pasalpasal yang relevan dengan penjaminan mutu pendidikan tinggi sebagaimana dikemukakan di bawah ini.

1. Tugas dan Wewenang Menteri Pendidikan dan Kebudayaan (Mendikbud) Di dalam pasal 7 ayat (3) huruf c UU Dikti ditetapkan bahwa tugas dan wewenang Menteri atas peneyelenggaraan pendidikan tinggi meliputi peningkatan penjaminan mutu, relevansi, keterjangkauan, pemerataan yang berkeadilan, dan akses pendidikan tinggi secara berkelanjutan.

2. Sistem Penjaminan Mutu

Di dalam pembahasan Rancangan UU Dikti di Dewan Perwakilan rakyat, disepakati bahwa ruh dari UU Dikti adalah penjaminan mutu pendidikan tinggi. Hal ini kemudian dibuktikan dengan pengaturan penjaminan mutu pendidikan tinggi dalam hal 19 satu) bab tersendiri, yaitu bab III UU Dikti berjudul Penjaminan Mutu yang terdiri atas 5 (lima) bagian. 
3. Sistem Penjaminan Mutu Pendidikan Tinggi (SPM Dikti) Menurut Pasal 51 UU Dikti, Pendidikan Tinggi yang bermutu merupakan pendidikan tinggi yang menghasilkan lulusan yang mampu secara aktif mengembangkan potensinya dan menghasilkan ilmu pengetahuan dan/atau teknologi yang berguna bagi masyarakat, bangsa dan negara. Untuk mendapatkan pendidikan tinggi yang bermutu tersebut, pemerintah menyelenggarakan System Penjaminan Mutu Pendidikan Tinggi (SPM Dikti).

Pengertian, Tujuan, dan Fungsi Sistem Penjaminan Mutu Pendidikan Tinggi

1. Pengertian SPM Dikti

Merupakan kegiatan sistematik untuk meningkatkan mutu pendidikan tinggi secara berencana dan berkelanjutan. Sementara itu, mutu pendidikan tinggi adalah tingkat kesesuaian antara penyelenggara pendidikan tinggi dengan Standar Dikti yang terdiri atas SN Dikti dan Standar Dikti yang ditetapkan oleh setiap perguruan tinggi.

2. Tujuan SPM Dikti

Menjamin pemenuhan Standar Dikti secara sistematik dan berkelanjutan, sehingga tumbuh dan berkembang budaya mutu di setiap perguruan tinggi di Indonesia. 


\section{Fungsi SPM Dikti}

Mengendalikan penyelenggaraan pendidikan tinggi oleh setiap perguruan tinggi untuk mewujudkan pendidikan tinggi yang bermutu.

\section{Sistem Penjaminan Mutu Internal (SPMI)}

Sebagaimana ditetapkan dalam Pasal 53 UU Dikti, SPM Dikti terdiri atas SPMI dan SPME atau akreditasi. SPMI adalah kegiatan sistematik penjaminan mutu pendidikan tinggi oleh setiap perguruan tinggi secara otonom atau mandiri untuk mengendalikan dan meningkatkan penyelenggaraan pendidikan tinggi secara berencana dan berkelanjutan. Dengan demikian setiap perguruan tinggi dapat mengembangkan sendiri SPMI antara lain sesuai dengan latar belakang sejarah, nilai dasar yang menjiwai pendirian perguruan tinggi itu, jumlah program studi dan sumber daya manusia, sarana dan prasarana perguruan tinggi tersebut tanpa campur tangan pihak lain. Sebagai contoh, SPMI di Universitas tidak cocok diimplementasikan di sekolah tinggi, demikian pula SPMI di pperguruan tinggi kelas dunia tidak cocok digunakan diperguruan tinggi dengan visi local.

Implementasi SPMI adalah tindakan kongkrit setiap perguruan tinggi mulai dari:

1. menyusun dan menetapkan seluruh Dokumen SPMI yaitu Kebijakan, Manual, Standar, dan Formulir SPMI; 
2. Melaksanakan isi dari dokumen tersebut terutama Standar SPMI;

3. Mengevaluasi dan mengendalikan pelaksanaan dari isi dokumen SPMI tersebut; dan

4. Meningkan mutu atas isi dari dokumen SPMI itu.

\section{Penjaminan Mutu di Lingkungan Fakultas Ekonomi dan Bisnis Universitas Mataram (FEB Unram)}

Dalam rangka meningkatkan kualitas mutu pendidikan sesuai dengan Standar Nasional Pendidikan Tinggi (SNPT), Fakultas Ekonomi dan Bisnis Universitas Mataram membentuk gugus dan unit Penjaminan Mutu Fakultas Ekonomi dan Bisnis Universitas Mataram untuk melakukan evaluasi terhadap penyelenggaraan berbagai program dan kegiatan pembelajaran di lingkungan Fakultas Ekonomi Unram. Gugus dan unit Penjaminan Mutu melaksanakan beberapa kegiatan antara lain:

- Penyusunan Instrumen Evaluasi

- Penyusunan POB

- Evaluasi Pembelajaran

- Evaluasi Penelitian

- Evaluasi Pengabdian pada Masyarakat

- Evaluasi Pembimingan Tugas Akhir 
Khusus Penjaminan mutu Program Studi Akuntansi dilaksanakan oleh unit penjaminan Mutu Program Studi Akuntansi. Unit ini berada dibawah Gugus Penjaminan Mutu Fakultas Ekonomi dan Bisnis Universitas Mataram. Dalam melakukan penjaminan mutu, Unit Penjaminan Mutu membuat berbagai standar yang akan diacu dalam pelaksanaan kegiatan. Standarstrandar tersebut dibuat dan dikoordinasikan dengan pengelola Program Studi. Selain itu, Unit Penjaminan Mutu juga membuat Manual Mutu yang merupakan dokumen penjaminan mutu. Selain itu juga disiapkan berbagai instrumen yang diperlukan dalam melakukan evaluasi berbagai kegiatan akademik yang ada.

\section{Kinerja dan Penilaiannya}

Kinerja adalah hasil-hasil fungsi pekerjaan (kegiatan seseorang) atau kelompok dalam suatu organisasi yang dipengaruhi oleh berbagai faktor untuk mencapai tujuan organisasi dalam periode waktu tertentu" (Tika, 2006:121). Penilaian kinerja merupakan suatu fungsi dari motivasi dan kemampuan. Untuk menyelelesaikan tugas atau pekerjaan seseorang sepatutnya memiliki derajat kesediaan dan tingkat kemampuan tertentu. Kesediaan dan keterampilan seseorang tidaklah cukup efektif untuk mengerjakan sesuatu tanpa pemahaman yang jelas tentang apa yang dikerjakan dan bagaimana mengerjakannya. Kinerja merupakan prilaku nyata 
yang ditampilkan setiap orang sebagai prestasi kerja yang dihasilkan oleh karyawan sesuai dengan perannya dalam perusahaan. Menurut Robbins (2001), kinerja adalah ukuran mengenai apa yang dikerjakan dan apa yang tidak dikerjakan oleh karyawan. Sedangkan menurut Mangkunegara (2011) prestasi kerja berasal dari kata job performance atau actual performance, yaitu hasil kerja secara kualitas dan kuantitas yang dicapai oleh seorang pegawai dalam melaksanakan tugasnya sesuai dengan tanggungjawab yang diberikan kepadanya. Kinerja dosen merupakan salah satu faktor penentu keberhasilan proses belajar mengajar di perguruan tinggi.

Penilaian kinerja (performance appraisa) adalah suatu proses yang digunakan pimpinan untuk menentukan apakah seorang karyawan melakukan pekerjaannya sesuai dengan tugas dan tanggung jawabnya (Mangkunegara, 2011).

Penilaian kinerja karyawan pada dasarnya merupakan penilaian yang sistematik terhadap penampilan kerja karyawan itu sendiri dan terhadap taraf potensi karyawan dalam upayanya mengembangkan diri untuk kepentingan perusahaan/ organisasi (Martoyo, 2000: 92).

Menurut Simamora (1997: 421) tujuan penilaian kinerja karyawan terdiri dari: tujuan pokok penilaian kinerja adalah menghasilkan informasi yang akurat dtentang prilaku dan evaluasi kerja anggota organisasi. 
Sedangkan tujuan khususnya, yaitu sebagai alat evaluasi dan pengembangan. Penilaian kinerja sebagai alat dalam pengambilan keputusan oleh pimpinan bermanfaat baik bagi karyawan untuk mengetahui kekurangan, potensi, tujuan, rencana dan pengembangan karir karyawan. Sedangkan bagi perusahaan bermanfaat dalam pengambilan keputusan identifikasi, kebutuhan program pendidikan dan latihan, rekrutmen, seleksi, penempatan karyawan, promosi (pengembangan karir), dan berbagai aspek lain dari keseluruhan proses manajemen secara efektif.

Penilaian kinerja merupakan mekanisme penting bagi manajemen untuk digunakan dalam menjelaskan tujuan dan standar kinerja dan memotivasi kinerja individudi waktu berikutnya.penilaian kinerja menjadi basis bagi keputusan-keputusan yang mempengaruhi gaji, promosi, pemberhentian, pelatihan,transfer, dan kondisi kepegawaian lainnya, tidak terkecuali Dosen yang berperan sebagai tenaga pendidik pada Perguruan Tinggi.

\section{Kinerja Dosen}

UU Nomor 14 Tahun 2005 tentang Guru dan Dosen, dan Peraturan Pemerintah Republik Indonesia Nomor 37 Tahun 2009 tentang Dosen, disebutkan bahwa dosen adalah pendidik profesional dan ilmuwan dengan tugas utama mentransformasikan, mengembangkan dan menyebarluaskan 
ilmu pengetahuan, teknologi, dan seni melalui pendidikan, penelitian dan pengabdian kepada masyarakat (Tridarma Perguruan Tinggi). Kinerja Depdiknas (2004), menyatakan kinerja dosen adalah kemampuan untuk melaksanakan pekerjaan atau tugas yang dimiliki dosen dalam menyelesaikan suatu pekerjaannya. Kinerja atau performansi dapat diartikan sebagai presentasi kerja, pelaksanaan kerja, pencapaian kerja, hasil kerja atau unjuk kerja (LAN, 2004). Sejalan dengan itu Smith (1982: 393) menyatakan, kinerja adalah "..output drive from processes, human or otherwise." Jadi, kinerja merupakan hasil atau keluaran dari suatu proses. Untuk lebih memahami tentang kinerja dosen. Kriteria kinerja pendidikan menurut Blazey, et al. (2001: 31) bertujuan untuk: (1) meningkatkan kinerja, kapabilitas, dan output pendidikan, (2) mempermudah komunikasi dan tukar menukar informasi tentang praktik pendidikan yang terbaik dengan berbagai tipe institusi pendidikan, dan (3) sebagai alat untuk memahami dan meningkatkan kinerja institusi pendidikan serta pedoman dalam perencanaan stratejik.

Kualitas dan kuantitas Tri Dharma Perguruan Tinggi sangat penting dalam upaya untuk membekali para mahasiswa dengan seperangkat ilmu pengetahuan, keterampilan. Bekal ilmu pengetahuan, keterampilan tersebut akan menjadi kompetensi setiap mahasiswa yang bisa diterapkan baik itu masih dalam masa kuliah atau setelah lulus nantinya. Untuk menghasilkan 
tenaga pendidik yang kompeten sejalan dengan Visi dan Misi Universitas Mataram tentunya memerlukan berbagai upaya yang yang terukur dan berkesinambungan. Banyak upaya yang bisa dilakukan agar tujuan tersebut dapat dicapai, salah satunya melalui penilaian kinerja dosen. Penilaian kinerja dosen dilingkungan Unram merupakan bagian dari upaya untuk menjamin mutu pendidikan tinggi seperti yang diharapkan oleh UU Dikti. Penilaian ini dilakukan oleh Tim Gugus maupun Unit Penjaminan Mutu yang sudah dibentuk. Aspek penilaian kinerja dosen ini mencakup penilaian terhadap seluruh aspek kegiatan Tri Dharma Perguruan Tinggi terdiri dari penilaian PBM, penelitian dan pengabdian masyarakat. Penilaian PBM dilaksanakan dengan metode penyebaran kuesioner kepada mahasiswa, dilaksanakan secara tertutup tanpa mencantumkan nama mahsiswa selaku koresponden sebagai penilaian. Aspek-aspek yang terungkap dalam penilaian kinerja dosen yang dinilai masih perlu ditingkatkan akan sangat bermanfaat jika perbaikan dan penyempurnaannya dapat direalisasikan sesegera mungkin sehingga hasilnya juga bisa dirasakan oleh mahasiswa dalam pelaksanaan semerter berikutnya.

\section{Pengembangan Hipotesis}

Setiap perguruan tinggi dapat mengembangkan sendiri SPMI antara lain sesuai dengan latar belakang sejarah, nilai dasar yang menjiwai pendirian 
perguruan tinggi itu, jumlah program studi dan sumber daya manusia, sarana dan prasarana perguruan tinggi tersebut tanpa campur tangan pihak lain.

Universitas Mataram (Unram) yang merupakan salah satu Perguruan Tinggi Negeri di Nusa Tenggara Barat tentunya juga tunduk pada berabagai aturan yang dikeluarkan oleh Pemerintah tentang Pendidikan, tidak terkecuali UU Dikti yang memuat tentang penjaminan mutu pelaksanaan pendidikan di lingkungan perguruan tinggi. Dalam Peraturan Meneteri Pendidikan dan Kebudayaan RI Nomor 116 Tahun 2014 tentang Organisasi dan Tata Kerja Uniersitas Mataram membentuk lembaga yang merupakan unsure pelaksana akademik di bawah Rektor yang melaksanakan sebagian tugas dan fungsi di bidang penelitian, pengabdian kepada Masyarakat, penjaminan mutu dan pengembangan pendidikan.

Fakultas Ekonomi dan Bisnis Unram (FEB Unram) merupakan salah satu unit pendidikan yang secara rutin menjalankan UU Dikti terkait dengan penjaminan mutu. Untuk mendukung UU tersebut, FEB Unram membentuk gugus dan unit penjaminan mutu untuk melakuukan evaluasi terhadap penyelenggaraan berbagai program dan kegiatan pembelajaran di Lingkungan Fakultas Ekonomi dan Bisnis Universitas Mataram. Evaluasi dilaksanakan oleh Gugus Penjaminan Mutu fakultas dibantu oleh unit penjaminan masing-masing jurusan dan program studi yang ada di 
lingkungan FEB Unram, salah satunya adalah unit penjaminan mutu Jurusan/Program Studi Akuntansi.

Unit Penjaminan mutu Program Srudi Akuntansi berada di bawah Gugus Penjaminan Mutu FEB Unram. Dalam melakukan penjaminan mutu, unit penjaminan mutu membuat berbagai standar yang akan diacu dalam pelaksanaan kegiatan. Standar-standar tersebut dibuat dan dikoordinasikan dengan pengelolan Program Studi. Gugus dan Penjaminan Mutu FEB Mataram melaksanakan beberapa kegiatan antara lain : a) Penyusunan Instrumen evaluasi; b) penyusunan $\mathrm{POB}$; c) Evaluasi penelitian; d) Evaluasi pengabdian pada Masyarakat; e) Evaluasi pembimbingan tugas akhir.

Khusus untuk evaluasi kegiatan pembelajaran dilaksanakan dengan menilai ketersediaan silabus, kehadiran dosen dalam perkuliahan, kinerja dosen dalam perkuliahan serta kepatuhan dosen dalam menyerahkan nilai ujian. Evaluasi juga dilakukan pada proses perkuliahan dengan menilai kesiapan ruang kuliah dalam hal kebersihan ruang dan ketersediaan peralatan penunjang perkuliahan serta kenyamanan ruang kuliah. Kegiatan penjaminan mutu di Lingkungan FEB Unram juga melibatkan mahasiswa sebagai bagian dari pemangku kepentingan fakultas. Keterlibatan mahasiswa dalam kegiatan penjaminan mutu diantaranya adalah dengan memberikan penilaian atas kinerja dosen dalam perkuliahan dan pembimbingan tugas 
Yusli Mariadi., Isnawati, \& Zuhrotul Isnaini : Dampak Nilai Final Terhadap Kinerja .....

akhir. Penilaian dilakukan dengan memberikan kuesioner baik secara manual maupun melalui Google Form agar diperoleh penilaian yang lebih representatif dari para mahasiswa.

Selama ini Penilaian kinerja dosen dalam perkuliahan dilakukan dengan penyebaran kuesioner untuk mengetahui respon/pendapat mahasiswa selama perkuliahan yang dilakukan. Penilaian dilakukan terhadap 10 (sepuluh) unsure dengan Skala penilaian yang digunakan $1-5$ dimana nilai $5=$ sangat baik; nilai $4=$ baik, nilai $3=$ cukup, nilai $2=$ kurang, nilai $1=$ sangat kurang. Dan sejau ini penilain mahasiswa terhadap kinerja dosen berbeda-beda untuk setiap semesternya. seperti halnya yang tertuang pada Laporan penjaminan Mutu Program Studi D3 Akuntansi untuk semester Gasal dan Genap pada Tahun ajaran 2016/2017. Hasil evaluasi kinerja dosen menurut mahasiswa pada semester Gasal 2016/2017 memperlihatkan hasil rata-rata sebesar 4,14. Hal ini menunjukkan mahasiswa menganggap bahwa dalam pemberian perkuliahan dosen telah melakukan tugasnya dengan baik. Sedangkan pada semester Genap 2016/2017 menunjukkan hasil yang berbeda dengan semester sebelumnya. Rata-rata nilai kinerja dosen dalam perspektif mahasiswa sebesar 3,89. Hal ini memberikan arti bahwa mahasiswa menganggap bahwa dalam memberikan perkuliahan dosen telah melakukan tugasnya dengan cukup baik. Berdasarkan latar belakang dan kajian teori 
terkait dengan studi peristiwa, maka pengembangan hipotesis atas jawaban sementara perumusan masalah adalah sebagai berikut:

\section{Ha : Rata-Rata Kinerja Dosen Sebelum dan Sesudah Pemberian (Pengumuman) Nilai Final berbeda secara signifikan dalam Perspektif Mahasiswa Akuntansi.}

\section{METODE PENELITIAN}

\section{Jenis Penelitian}

Jenis penelitian ini adalah penelitian deskriptif. Menurut Sugiyono (2011), penelitian deskriptif adalah sebuah penelitian yang bertujuan untuk memberikan atau menjabarkan suatu keadaan atau fenomena yang terjadi saat ini dengan menggunakan prosedur ilmiah untuk menjawab masalah actual. Penelitian ini menggunakan metode event study untuk menguji Pengumuman nilai final terhadap suatu peristiwa atau kejadian tertentu (Iskandar dalam Sparta, 2010). Studi peristiwa dalam penelitan ini adalah Pengumuman Nilai final yang diperoleh setiap mahasiswa dari dosen.

\section{Lokasi Penelitian}

Penelitian ini dilakukan di Lingkungan Fakultas Ekonomi dan Bisnis Universitas Mataram, yaitu mengkaji data-data yang dikumpulkan dari responden dalam hal ini mahasiswa akuntansi mengenai kinerja dosen. 


\section{Jenis dan Sumber Data Penelitian}

Data penelitian ini adalah data sekunder dan data primer. Data sekunder berupa Jumlah Mahasiswa Akuntansi FEB Unram dan lain sebagainya. Sumber data lainnya berupa studi kepustakaan, untuk mencari teori-teori yang berhubungan dengan topik penelitian. Sedangkan data primer berupa informasi-informasi yang dibutuhkan dalam penelitian ini, tetapi tidak tertera pada laporan yang dipublikansikan, sehingga harus diperoleh melalui proses wawancara, penyebaran kuesioner dan lain sebagainya.

\section{Teknik Pegumpulan Data Penelitian}

Pengumpulan data dilakukan dengan teknik penyebaran kuesioner, wawancara dan browsing data yang dipublikasikan oleh Fakultas Ekonomi Dan Bisnis Universitas Mataram. Adapun teknik wawancara ini dilakukan untuk memperoleh informasi atau data yang tidak terdapat pada situs resmi, seperti informasi mengenai faktor-faktor yang mempengaruhi penilaian mahasiswa tersebut kepada dosen yang bersangkutan

\section{Populasi dan Sampel Penelitian}

Populasi dalam penelitian ini adalah semua mahasiswa akuntansi yang aktif pada tahun ajaran 2018/2019. Sedangkan populasi untuk dosen yang dinilai adalah seluruh dosen yang mengajar pada jurusan akuntansi FEB 
Unram pada tahun ajaran 2018/2019. Sampel adalah bagian dari jumlah dan karakteristik yang dimiliki oleh populasi. Metode sampel dalam penelitian ini adalah purposive sampling, yaitu pengambilan sampel secara sengaja sesuai dengan kebutuhan penelitian. Adapun yang menjadi criteria dalam pengambilan sampel penelitian ini adalah mahasiswa Akuntansi yang sedang menempuh semester dua dan semester empat. Setelah itu setiap mahasiswa yang dijadikan sampel responden tersebut akan disaring lagi dalam rangka dalam rangka menghemat waktu, biaya dan tenaga serta mempercepat proses pengumpulan data. Dalam penelitian ini metode pengambilan sampel yang digunakan adalah teknik simple random sampling yaitu setiap responden mempunyai probabilitas yang sama untuk dipilih (Kountur, 2004: 139). Untuk mendapatkan sampel yang dapat menggambarkan populasi penelitian, maka dalam penentuan sampel digunakan rumus Slovin (Umar, 2004: 108) sebagai berikut:

$$
\begin{array}{ll}
n=\frac{N}{N e^{2}+1} & \text { Dimana: } \\
& \mathrm{n}=\text { Jumlah Sampel } \\
& \mathrm{N}=\text { Ukuran Populasi } \\
& \mathrm{e}=\text { toleransi nilai persentase yang diharapkan tidak } \\
& \text { menyimpang dari } 10 \% .
\end{array}
$$

\section{Analisis Data Penenlitian}

Langkah 1: Melakukan tabulasi hasil jawaban responden (mahasiswa) yang dituangkan dalam kuesioner (instrument penelitian). 
Langkah 2: Melakukan analisa untuk mengetahui kinerja dosen menurut pandangan mahasiswa, baik sebelum maupun sesudah pemberian nilai final oleh dosen kepada mahasiswa.

Langkah 3: Melakukan pengujian Statistik untuk menguji perbedaan rata rata kinerja dosen sebelum dan sesudah pemberian nilai dalam perspektif mahasiswa akuntansi. Pengujian yang dilakuakan adalah Uji Beda dengan langkah-langkah pengujian sebagai berikut:

\section{Uji Kelayakan Instrumen Penelitian}

Instrumen yang akan digunakan dalam penelitian ini adalah kuesioner/angket yang digunakan untuk menilai kinerja dosen dalam proses belajar mengajar, usia, pendidikan, masa kerja , motivasi kerja, kepuasan kerja, persepsi imbalan dan persepsi supervise Uji Validitas dan Reliabilitas. Pengolahan data hasil uji coba kuesioner dengan bantuan computer program SPSS for window untuk menguji validitas dan reliabilitas.

\section{Uji Beda (Parired Sample t- Test)}

Studi peristiwa (event study) merupakan studi yang mempelajari reaksi pasar terhadap suatu peristiwa yang informasinya dipublikasikan sebagai suatu pengumuman. Event study digunakan untuk menguji kandungan informasi dari suatu pengumuman dan dapat juga digunakan untuk menguji efisiensi pasar bentuk setengah kuat. 


\section{HASIL PENELITIAN DAN PEMBAHASAN}

\section{Deskripsi Data Penelitian}

Berikut adalah gambaran penilaian mahasiswa terhadap dosennya untuk periode sebelum dan setelah pemberian nilai final.

Tabel 1:Paired Samples Statistics

\begin{tabular}{|c|c|c|c|c|c|}
\hline & & Mean & $\mathrm{N}$ & $\begin{array}{c}\text { Std. } \\
\text { Deviation }\end{array}$ & $\begin{array}{l}\text { Std. Error } \\
\text { Mean }\end{array}$ \\
\hline \multirow[t]{2}{*}{ Pair } & Sebelum & 4.042 & 66 & .3775 & .0465 \\
\hline & Sesudah & 3.945 & 66 & .5121 & .0630 \\
\hline
\end{tabular}

\section{Uji validitas}

Dan hasil Uji validitas instrument penelitian ini dapat dilihat pada tabel 2 di bawah ini:

Tabel 2 : Uji Validitas Instrumen Penelitian Correlations

\begin{tabular}{|c|c|c|c|c|c|c|c|c|c|c|c|c|}
\hline & Q1 & Q2 & Q3 & Q4 & Q5 & Q6 & Q7 & Q8 & Q9 & Q10 & Q11 & Ket \\
\hline $\begin{array}{|ll|}\text { Q1 } & \text { Pearson } \\
& \text { Correlation }\end{array}$ & & $.689^{*}$ & $.399^{*}$ & $.586^{*}$ & $.573^{*}$ & $.555^{*}$ & $.530^{*}$ & $.600^{*}$ & $.644^{*}$ & $.493^{*}$ & $.768^{*}$ & valid \\
\hline \begin{tabular}{|ll} 
Q2 & Pearson \\
Correlation
\end{tabular} & $.689^{*}$ & & $.554^{*}$ & $.552^{*}$ & $.625^{*}$ & $.643^{*}$ & $.621^{*}$ & $.676^{*}$ & $.609^{*}$ & $.532^{*}$ & $.821^{*}$ & valid \\
\hline \begin{tabular}{|ll} 
Q3 & Pearson \\
& Correlation
\end{tabular} & $.399^{*}$ & $.554^{*}$ & 1 & $.679^{*}$ & $.409^{*}$ & $.431^{*}$ & $.458^{*}$ & $.495^{*}$ & $.568^{*}$ & $.496^{*}$ & $.700^{*}$ & id \\
\hline \begin{tabular}{|l} 
Q4 \\
Pearson \\
Correlation
\end{tabular} & $.586^{*}$ & $.552^{*}$ & $.679^{*}$ & & $.480^{*}$ & $.510^{*}$ & $.541^{*}$ & $.604^{*}$ & $.667^{*}$ & $.468^{*}$ & $.774^{*}$ & |valid \\
\hline $\begin{array}{|ll|}\text { Q5 } & \text { Pearson } \\
& \text { Correlation } \\
\end{array}$ & $.573^{*}$ & $.625^{*}$ & $409^{*}$ & $.480^{*}$ & 1 & $.790^{*}$ & $.620^{*}$ & $.672^{*}$ & $.648^{*}$ & $.496^{*}$ & $.796^{*}$ & valid \\
\hline $\begin{array}{|ll|}\text { Q6 } & \text { Pearson } \\
& \text { Correlation }\end{array}$ & $.555^{*}$ & $.643^{*}$ & $431^{*}$ & $.510^{*}$ & $.790^{*}$ & & $.646^{*}$ & $.729^{*}$ & $.634^{*}$ & $.567^{*}$ & $.819^{*}$ & valid \\
\hline \begin{tabular}{|ll} 
Q7 & Pearson \\
& Correlation
\end{tabular} & $.530^{*}$ & $.621^{*}$ & $458^{*}$ & $.541^{*}$ & $.620^{*}$ & $.646^{*}$ & & $.687^{*}$ & $.649^{*}$ & $.455^{*}$ & .776 & id \\
\hline
\end{tabular}




\begin{tabular}{|c|c|c|c|c|c|c|c|c|c|c|c|c|c|}
\hline 8 & $\begin{array}{l}\text { Pearson } \\
\text { Correlation }\end{array}$ & $.600^{*}$ & $.676^{*}$ & $.495^{*}$ & $.604^{*}$ & $.672^{*}$ & $.729^{*}$ & $.687^{*}$ & 1 & $.788^{*}$ & $.628^{*}$ & $.867^{*}$ & valid \\
\hline 29 & \begin{tabular}{l|} 
Pearson \\
Correlation
\end{tabular} & $.644^{*}$ & $.609^{*}$ & $.568^{*}$ & $\mid .667^{*}$ & $.648^{*}$ & $.634^{*}$ & $.649^{*}$ & $.788^{*}$ & 1 & $.657^{*}$ & $.864^{*}$ & valid \\
\hline $\begin{array}{l}\text { Q1 } \\
0\end{array}$ & \begin{tabular}{l|} 
Pearson \\
Correlation
\end{tabular} & $.493^{*}$ & $.532^{*}$ & $.496^{*}$ & $\mid .468^{*}$ & $.496^{*}$ & $.567^{*}$ & $.455^{*}$ & $.628^{*}$ & $.657^{*}$ & . & $733^{*}$ & valid \\
\hline \multirow[t]{3}{*}{$\begin{array}{l}\mathrm{Q} 1 \\
1\end{array}$} & \begin{tabular}{l|} 
Pearson \\
Correlation
\end{tabular} & $.768^{*}$ & $.821^{*}$ & $.700^{*}$ & $.774^{*}$ & $.796^{*}$ & $\mid .819^{*}$ & $.776^{*}$ & $.867^{*}$ & $.864^{*}$ & $.733^{*}$ & 1 & \\
\hline & $\begin{array}{l}\text { Sig. (2- } \\
\text { tailed) }\end{array}$ & .000 & .000 & .000 & .000 & .000 & .000 & .000 & $\mid .000$ & $\mid .000$ & .000 & & \\
\hline & $\mathrm{N}$ & 91 & 91 & 91 & 91 & 91 & 91 & 91 & 91 & 91 & 91 & 91 & \\
\hline
\end{tabular}

**. Correlation is significant at the 0.01 level (2-tailed).

\section{Uji Reliabilitas}

Hasil perhitungan reliabilitas kuesioner dalam penelitian ini dapat dilihat dari tabel 3 di bawah ini:

Tabel 3: Case Processing Summary

\begin{tabular}{|ll|r|r|}
\hline & & \multicolumn{1}{|c|}{$\mathrm{N}$} & \multicolumn{1}{c|}{$\%$} \\
\hline Cases & Valid & 91 & 100.0 \\
& Excluded $^{a}$ & 0 & .0 \\
& Total & 91 & 100.0 \\
\hline
\end{tabular}

a. Listwise deletion based on all variables in the procedure.

Tabel 4: Reliability Statistics

\begin{tabular}{|c|r|}
\hline $\begin{array}{c}\text { Cronbach's } \\
\text { Alpha }\end{array}$ & N of Items \\
\hline .781 & 11 \\
\hline
\end{tabular}

Sumber : Lampiran 1 


\section{Uji Normalitas Data}

Berikut adalah hasil Uji Normalitas pada data penelitian ini dapat dilihat pada tabel 5 .

Tabel 5: One-Sample Kolmogorov-Smirnov Test

\begin{tabular}{|c|c|c|c|}
\hline & Sebelum & Sesudah \\
\hline \multicolumn{2}{|l|}{$\mathrm{N}$} & 66 & 66 \\
\hline \multirow[t]{2}{*}{ Normal Parameters ${ }^{\mathrm{a}}$} & Mean & 4.042 & 3.945 \\
\hline & Std. Deviation & .3775 & .5121 \\
\hline \multirow{3}{*}{$\begin{array}{l}\text { Most Extreme } \\
\text { Differences }\end{array}$} & Absolute & .131 & .085 \\
\hline & Positive & .070 & .079 \\
\hline & Negative & -.131 & -.085 \\
\hline \multicolumn{2}{|l|}{ Kolmogorov-Smirnov Z } & 1.067 & .692 \\
\hline \multicolumn{2}{|l|}{ Asymp. Sig. (2-tailed) } & .205 & .725 \\
\hline \multicolumn{2}{|c|}{ a. Test distribution is Normal. } & & \\
\hline
\end{tabular}

\section{Uji Beda Sampel Berpasangan (Paired Sample t-Test)}

Berikut adalah hasil paired sample t-test pada penelitian ini dapat dilihat pada tabel 6 di bawah ini:

Tabel 6: Paired Samples Test

\begin{tabular}{|c|c|c|c|c|c|c|c|c|}
\hline & \multicolumn{5}{|c|}{ Paired Differences } & \multirow[b]{3}{*}{$\mathrm{t}$} & \multirow[b]{3}{*}{ df } & \multirow{3}{*}{$\begin{array}{l}\text { Sig. (2- } \\
\text { tailed) }\end{array}$} \\
\hline & \multirow{2}{*}{$\begin{array}{c}\text { Mea } \\
\mathrm{n}\end{array}$} & \multirow{2}{*}{$\begin{array}{l}\text { Std. } \\
\text { Deviati } \\
\text { on }\end{array}$} & \multirow{2}{*}{$\begin{array}{l}\text { Std. } \\
\text { Error } \\
\text { Mean }\end{array}$} & \multicolumn{2}{|c|}{$\begin{array}{c}95 \% \\
\text { Confidence } \\
\text { Interval of the } \\
\text { Difference }\end{array}$} & & & \\
\hline & & & & Lower & Upper & & & \\
\hline $\begin{array}{ll}\text { Pair } & \text { Sebelum - } \\
1 & \text { Sesudah }\end{array}$ & $\begin{array}{r}.097 \\
0\end{array}$ & .5849 & .0720 & -.0468 & .2408 & $\begin{array}{r}1.34 \\
7\end{array}$ & 65 & .183 \\
\hline
\end{tabular}




\section{Interpretasi Hasil Penelitian}

Hipotesis penelitian ini menyatakan bahwa rata-rata kinerja dosen sebelum dan sesudah pemberian (pengumumam) nilai final berbeda secara signifikan dalam perspektif Mahasiswa Akuntansi yang artinya bahwa pemberian nilai memiliki dampak terhadap penilaian mahasiswa pada kinerja dosennya. Untuk menguji kebenaran hipotesis ini, maka dilakukan uji t (sample t- test) seperti yang terlihat pada tabel $4.4 \mathrm{di}$ atas menunjukkan bahwa tingkat signifikansi lebih besar dari 0,05 yaitu sebesar 0,183 . Hasil ini menunjukkan bahwa tidak terdapat perbedaan penilaian mahasiswa terhadap dosen akuntansi sebelum dan sesudah adanya penilaian final.

Hasil penelitian ini menolak hipotesis yang sudah dibangun yang menyatakan bahwa terdapat perbedaan nilai rata-rata penilaian mahasiswa terhaap kinerja dosen akuntansi sebelum dan sesudah pemberian nilai final. Yang artinya bahwa pemberian nilai final akan memberikan dampak terhadap penilaian kinerja dosen dilihat dari perspektif mahasiswa akuntansi. Namun hasil penelitian ini menunjukkan bahwa pemberian nilai final tidak berdampak terhadap penilaian kinerja dosen akuntansi dari perspektif mahasiswa akuntansi. 


\section{SIMPULAN}

Berdasarkan uraian pada bab Hasil dan pembahasan, maka penelitian ini dapat menarik beberapa kesimpulan sebagai berikut:

1. Penilaian mahasiswa akuntansi terhadap kinerja dosennya sebelum pemberian nilai final rata-rata sebesar 4 . Angka ini berada pada interval kriteria Baik, maka hal ini menunjukkan bahwa rata-rata mahasiswa akuntansi menyatakan dosennya berkinerja baik.

2. Penilaian mahasiswa akuntansi terhadap kinerja dosennya sebelum pemberian nilai final rata-rata sebesar 3.9. angka ini berada pada angka interval Baik, maka hal ini menunjukkan bahwa rata-rata mahasiswa akuntansi menyatakan dosennya berkinerja baik.

3. Pemberian nilai final ternyata tidak memberikan dampak pada penilaian mahasiswa akuntansi terhadap dosennya. Karena rata-rata penilaian mahasiswa akuntansi terhadap kinerja dosennya sebelum dan sesudah pemberian nilai final tidak memiliki perbedaan karena selisih rata-rata nilainya sama dengan nol. 


\section{DAFTAR PUSTAKA}

Chairy, Liche Seniati, 2005, Evaluasi Dosen sebagai Bentuk Penilaian Kerja, Workshop Evaluasi Kinerja Dosen oleh Mahasiswa. UIN Syarif Hidayatullah. Jakarta.

Dirjen Dikti, 2010, Pedoman Beban Kerja Dosen dan Evaluasi Pelaksanaan Tridharma Perguruan Tinggi, Jakarta.

Hendry Simamora. (1997). Manajemen Sumber Daya Manusia. Yogyakarta:

STIE YKPN.

Hermawan, Warsito, 1995, Pengantar Metodologi Penelitian, Jakarta: PT. Gramedia Pustaka.

I Gusti Made Sulindra. (2009). Analisis Kompetensi Kepribadian Dosen Berdasarkan Penilaian Persepsional. Media Bina IImiah UNSA. Sumbawa Besar.

Imam Ghozali. (2005). Aplikasi Analisis Multivariate Dengan Program SPSS. Cet. IV. Semarang: BP. UNDIP.

Kardoyo (2011). Analisis Penjaminan Mutu Fakultas Ekonomi: Pencapaian sasaran Mutu Akademik dan Kesesuaian Prosedur Akademmik Dengan Standar Mutu ISO 9001 : 2008. Jurnal Pendidikan Ekonomi Dinamika Pendidikan Vol. VI, No.2 Desember 2011. FE UNNES.

Kemenristek Dikti (2016). Pedoman Sistem Penjaminan Mutu. IBN:978-6027220-28-7. Jakarta.

Kountur, Ronny, 2004, Metode Penelitian untuk Penulisan Skripsi dan Tesis, Jakarta: Penerbit PPM.

Melayu S.P. Hasibuan. (2008). Manajemen Sumber Daya Manusia. Edisi Revisi. Jakarta: Penerbit Bumi Aksara. 
Mundarti (2007). Faktor-Faktor yang Mempengaruhi Kinerja Dosen Dalam Melaksanakan proses Belajar Mengajar di Prodi Kebidanan Magellang Politeknik Kesehatan Semarang Tahun Akademik 2005/2006. Tesis. Universitas Diponegoro Semarang.

Nurgiyantoro, B., et.al., 2002, Statistik Terapan untuk Penelitian IImu-IImu Sosial, Yogyakarta: Gadjah Mada University Press.

Prahatmaja, Nurmaya. 2004. Perilaku Pengguna dalam Mencari dan

Pemanfaatan Informasi di Pusat Dokumentasi Solopos, Bandung:

Fakultas Komunikasi Universitas Padjadjaran. Skripsi tidak dipublikasikan. Bandung.

Peraturan Menteri Pendidikan Dan Kebudayaan republic Indonesia Nomor 116

Tahun 2014 Tentang Organisasi Dan Tata Kerja Universitas Mataram.

Trisnaningsih (2011). Faktor-Faktor Yang Mempengaruhi Kinerja Dosen Akuntansi. Jurnal Akuntansi \& Auditing. Volume 8 No.1/November 2011; 1-94.

Undang-undang No. 14 Tahun 2005 Tetang Kompetensi Guru dan Dosen.

Sugiyono. (2008). Metode Penelitian Kuantitatif Kualitatif dan R\&D. Bandung:

CV.Alfabeta.

UU Nomor 14 Tahun 2005 tentang Guru dan Dosen Umar, Husein, 2004, Riset Sumber Daya Manusia, Jakarta : PT. Gramedia Pustaka Utama. Yahya Dan HIdayati (2014). Analisis Kompetensi Terhadap Penilaian Kinerja Dosen (Studi Kasus Dosen UIN Sultas Syarif Kasim RIAU). Jurnal Penelitian Sosial Keagamaan, Volume.17, No.1 Januari-Juni 2014. UIN Sultan Syarif Kasim Riau. 